University of Nebraska - Lincoln

DigitalCommons@University of Nebraska - Lincoln

Faculty Papers and Publications in Animal

Science

Animal Science Department

1991

\title{
The Effect of Cimaterol and Its Withdrawal on Carcass Composition and Meat Tenderness of Broiler Chickens
}

\author{
B. L. Gwartney \\ University of Nebraska-Lincoln \\ Chris R. Calkins \\ University of Nebraska-Lincoln, ccalkins1@unl.edu \\ Steven J. Jones \\ University of Nebraska-Lincoln, sjones1@unl.edu
}

Follow this and additional works at: https://digitalcommons.unl.edu/animalscifacpub

Part of the Animal Sciences Commons

Gwartney, B. L.; Calkins, Chris R.; and Jones, Steven J., "The Effect of Cimaterol and Its Withdrawal on Carcass Composition and Meat Tenderness of Broiler Chickens" (1991). Faculty Papers and Publications in Animal Science. 574.

https://digitalcommons.unl.edu/animalscifacpub/574

This Article is brought to you for free and open access by the Animal Science Department at DigitalCommons@University of Nebraska - Lincoln. It has been accepted for inclusion in Faculty Papers and Publications in Animal Science by an authorized administrator of DigitalCommons@University of Nebraska - Lincoln. 


\title{
THE EFFECT OF CIMATEROL AND ITS WITHDRAWAL ON CARCASS COMPOSITION AND MEAT TENDERNESS OF BROILER CHICKENS 1,2
}

\author{
B. L. Gwartney, C. R. Calkins and S. J. Jones
}

University of Nebraska ${ }^{3}$, Lincoln 68583-0908

\begin{abstract}
To examine the effects of cimaterol (CIM) and its withdrawal on meat tendemess and carcass composition, 21 - $d$-old broiler chickens $(n=288)$ were randomly assigned to one of nine treatments. For Treatments 1 through 6 , birds were fed a control diet or a diet containing $1 \mathrm{ppm}$ CIM until slaughter at 35, 42, or $49 \mathrm{~d}$ of age. Treatments 7 and 8 consisted of birds fed the CIM diet for $14 \mathrm{~d}$ and then withdrawn from CMM for either 7 or $14 \mathrm{~d}$ before slaughter ( 42 or $49 \mathrm{~d}$ of age). In Treatment 9 , birds were fed the CIM diet to 42 $\mathrm{d}$ of age, then withdrawn from CIM for $7 \mathrm{~d}$. Breast muscle (BM) weight, leg muscle (LM) weight, whole body weight, and BM and $L M$ cathepsin $B$ and $L$ activities were obtained on 12 birds/treatment. Body, LM and BM composition and BM shear values were obtained on 12 additional birds/treatment. Eight birds/treatment were used to balance the number of birds per pen. Leg muscle weight, as a percentage of whole body weight, was elevated in CIM-fed birds at all ages, and BM percentage was greater at $35 \mathrm{~d}$ of age $(P<.05)$. Leg muscle fat percentage was reduced at 35 and $42 \mathrm{~d}$ of age $(P<.05)$, and LM protein was elevated at 42 and $49 \mathrm{~d}$ of age $(P<.05)$ in CIM-fed birds. Percentage of protein in the BM of CIM-fed birds was elevated at 35 and $42 \mathrm{~d}$ of age. Protein content of the whole body was also increased at $35 \mathrm{~d}$ of age. Shear values were higher in $42-$ and 49-d-old CIM-fed birds. Withdrawal from CIM increased LM and BM fatness beyond that of controls $(P<.05)$, removed the differences in protein percentage, and removed the detrimental effects on shear value. No differences were found in total cathepsin $B$ and $L$ activities. Broiler chickens fed CIM have increased muscle protein percentage, decreased fat percentage, heavier muscle weights, and reduced meat tendemess. Withdrawal from CIM removed these differences.

Key Words: Cimaterol, Beta-Adrenergic Agonists, Tendemess, Poultry
\end{abstract}

J. Anim. Sci. 1991. 69:1551-1558

Introduction

Cimaterol (CIM), a beta-adrenergic agonist, has been recognized as a repartitioning agent capable of improving body composition in many animal species. Cimaterol increases muscle mass and decreases fat deposition in

\footnotetext{
${ }^{1}$ Paper number 9250, Journal series, Nebraska Agric. Res. Div., Inst. of Agric. and Nat. Resources.

${ }^{2}$ Cimaterol provided as a gift by American Cyanamid, Princeton, NJ.

${ }^{3}$ Dept. of Anim. Sci.

Received July 2, 1990.

Accepted October 24, 1990.
}

sheep (Beermann et al., 1986), swine (Jones et al., 1985), and broiler chickens (Morgan et al., 1989). However, this compound has been reported to reduce tendemess in poultry muscle (Morgan et al., 1989). With increased consumer demand for lean meat, the addition of beta-adrenergic agonists to poultry diets becomes a possible altemative in broiler production systems.

If feeding beta-agonists becomes an industry practice, withdrawal of the compounds may be necessary because a withdrawal period is required by regulation authorities for many feed additives. However, withdrawal from beta-agonists has not been extensively studied. 
Not only do regulatory agencies need to define a safe and effective withdrawal period, they also need to know and recognize what changes are occurring in the animal during the period of withdrawal. These changes can be related to composition and meat quality. The objectives of this study were to examine the effects of cimaterol and its withdrawal on muscle and carcass composition, meat tenderness, and catheptic enzyme activities in poultry.

\section{Experimental Procedure}

Two hundred eighty-eight 21-d-old Vantress $\times$ Arbor Acre broiler chickens of mixed sex were wing-banded with 144 birds randomly assigned to Battery 1 (two pens/ treatment, eight birds/pen) and 144 birds assigned to Battery 2. In this experiment, battery represented replication. After allocation of birds to the batteries was complete, treatments were assigned to pens within battery. Only 24 birds for each treatment were sampled. The extra eight birds/treatment were not sampled in this study; they were used to keep the number of birds/pen balanced. For every treatment, 12 randomly selected birds were slaughtered via cervical dislocation at the appropriate age (major kill periods at 35,42 , and $49 \mathrm{~d}$ of age). These birds were used to obtain muscle and body weights, cathepsin B and $L$ activities, and muscle shear values. In addition, $3 \mathrm{~d}$ before and $3 \mathrm{~d}$ after the kill periods, six birds/treatment (a total of 12/ treatment) were randomly selected and slaughtered to determine whole body and muscle composition. All birds had free access to tap water and were given ad libitum access to a $20 \%$ CP growing ration (3,131 kcal of ME $/ \mathrm{kg})$ consisting of $64.3 \%$ grain sorghum, $25.3 \%$ soybean meal $(47.5 \% \mathrm{CP}), 5.0 \%$ animal fat, and a vitamin and mineral supplement that contained 20\% CP and was 90\% DM. All nutritional requirements of the growing bird were met. Birds were housed in growing batteries with raised-wire floors at room temperature with continuous lighting. Each pen was $.48 \mathrm{~m}^{2}$ in size. This research was conducted during the summer months. Feed consumption was measured daily for the first $11 \mathrm{~d}$.

\footnotetext{
${ }^{4}$ Omega Engincering, Inc., Stamford, CT.
}

Cathepsin $B$ and $L$ activities were measured on the breast muscle (BM; Pectoralis major) and leg muscles (LM; Gastrocnemius and Peroneous longus). Shear values were measured on BM. Whole body, BM, and LM proximate composition was determined along with weights of the whole body, liver, fatpad, BM, and LM. Composition (moisture, fat, and protein) was measured using AOAC (1985) methods. Total cathepsin $B$ and $L$ activities were determined on muscle samples prepared using the procedures of Moeller et al. (1976). One BM and both LM were removed immediately postmortem, frozen in liquid $\mathrm{N}$, and stored at $-70^{\circ} \mathrm{C}$ for further analysis. Ten grams of muscle (from one BM or both LM) was homogenized in $40 \mathrm{ml}$ of ice-cold $.25 \mathrm{M}$ sucrose containing .02 $\mathrm{M} \mathrm{KCl}$. The homogenate was filtered through two layers of cheesecloth and the filtrate was adjusted to a pH of 7.3 with $1 \mathrm{~N} \mathrm{KOH}$. The pH-adjusted filtrate was centrifuged at $5,000 \times g$ for 20 min, and the supernatant was decanted and saved. The resulting pellet was resuspended in $35 \mathrm{ml}$ of the sucrose- $\mathrm{KCl}$ solution and recentrifuged. This supematant was decanted and combined with the previous supernatant. The total volume of supernatant was analyzed for protein content using the biuret method (Gomall et al., 1949). After protein determination, the samples were diluted according to an average protein concentration of all samples to attain similar protein levels $(.3 \mathrm{mg} / \mathrm{ml})$. Total and specific cathepsin $B$ and $L$ activities were measured over $30 \mathrm{~min}$ by the techniques of Barrett (1980) with a spectrofluorometer using $.05 \mu M$ substrate N-CBZ-L-phenylalanine-Larginine-4-methylcoumarinyl-7-amide, which is hydrolyzed by both cathepsins B and L (Barrett and Kirschke, 1981).

Breast muscle for shear value determination was aged on the carcass at room temperature for $2 \mathrm{~h}$ postmortem to prevent shortening. The $\mathrm{BM}$ was excised and placed in a $4^{\circ} \mathrm{C}$ cooler for $24 \mathrm{~h}$, allowing any postmortem enzymatic tenderization to occur, then frozen at $-70^{\circ} \mathrm{C}$. For shear value determination, the BM was removed from the freezer, allowed to temper at $4^{\circ} \mathrm{C}$ for approximately $14 \mathrm{~h}$, double-wrapped in aluminum foil and heated to an internal temperature of $82^{\circ} \mathrm{C}$ in a $177^{\circ} \mathrm{C}$ gas oven. Temperature was monitored using copperconstantan thermocouples of small diameter attached to an Omega digital thermometer ${ }^{4}$. 
TABLE 1. THE EFFECTS OF CIMATEROL AND ITS WITHDRAWAL ON INITLAL BODY WEIGHT (IBW), FINAL BODY WEIGHT (FBW), FAT PAD, AND LIVER WEIGHT OF BROLLER CHICKENS

\begin{tabular}{|c|c|c|c|c|c|c|c|c|c|}
\hline \multirow[b]{4}{*}{ Age and variable } & \multirow{2}{*}{\multicolumn{4}{|c|}{ Treatments $^{\mathrm{a}}$}} & \multicolumn{4}{|c|}{ Contrasts } & \multirow[b]{4}{*}{ SEM $^{\mathrm{b}}$} \\
\hline & & & & & \multirow{3}{*}{$\begin{array}{l}\text { CON } \\
\text { vs } \\
\text { Owd }\end{array}$} & \multirow{3}{*}{$\begin{array}{l}\text { CON } \\
\text { vs } \\
7 w d\end{array}$} & \multirow{3}{*}{$\begin{array}{l}\text { Owd } \\
\text { vs } \\
7 \text { wd }\end{array}$} & \multirow{3}{*}{$\begin{array}{l}\text { Owd } \\
\text { vs } \\
14 w d\end{array}$} & \\
\hline & \multirow[b]{2}{*}{$\mathrm{CON}$} & \multicolumn{3}{|c|}{ Cimaterol } & & & & & \\
\hline & & Owd & $7 w d$ & $14 w d$ & & & & & \\
\hline \multicolumn{10}{|l|}{35 Days } \\
\hline IBW, $\mathrm{g}$ & 517 & 521 & - & - & $\mathrm{NS}^{\mathrm{c}}$ & - & - & - & 3.24 \\
\hline FBW, & 1247 & 1174 & - & - & NS & - & - & - & 28.97 \\
\hline Fat pad, $\mathrm{g}$ & 24.14 & 17.09 & - & - & NS & 一 & - & - & 1.19 \\
\hline Liver, $g$ & 25.58 & 23.23 & - & - & NS & - & 一 & 一 & 1.01 \\
\hline \multicolumn{10}{|l|}{42 Days } \\
\hline IBW, $\mathbf{g}$ & 536 & 536 & 523 & - & NS & NS & NS & - & 一 \\
\hline FBW, $\mathrm{g}$ & 1690 & 1669 & 1606 & - & NS & NS & NS & - & - \\
\hline Fat pad, $\mathrm{g}$ & 28.46 & 27.28 & 25.21 & - & NS & NS & NS & - & - \\
\hline Liver, $\mathrm{g}$ & 32.26 & 30.27 & 27.86 & - & NS & NS & NS & - & 一 \\
\hline \multicolumn{10}{|l|}{49 Days } \\
\hline IBW, $\mathrm{g}$ & 522 & 528 & 534 & 521 & NS & NS & NS & NS & - \\
\hline FBW, $g$ & 1998 & 2066 & 2049 & 2018 & NS & NS & NS & NS & - \\
\hline Fat pad, $g$ & 40.40 & 43.78 & 38.34 & 41.05 & NS & NS & NS & NS & - \\
\hline Liver, $\mathrm{g}$ & 38.18 & 39.59 & 34.44 & 36.78 & NS & NS & NS & NS & - \\
\hline
\end{tabular}

${ }^{\circ} \mathrm{CON}=$ chickens fed 0 ppm cimaterol in diet and Cimaterol = chickens fed 1 ppm cimaterol in diet and withdrawn (wd) from cimaterol and fed $0 \mathrm{ppm}$ cimaterol for 0,7 , or $14 \mathrm{~d}$. Number of observations $=12 /$ treatment.

${ }^{b}$ Standard error of the means represents variables for 35,42 , and $49 d$ of age.

${ }^{c} \mathrm{NS}=$ nonsignificant differences $(P>.05)$.

After cooling at room temperature for $2 \mathrm{~h}$, a $3-\mathrm{cm} \times 3-\mathrm{cm} \times 1-\mathrm{cm}$ sample was removed from the thick, anterior portion of the BM using a handmade die. Three $1-\mathrm{cm} \times$ $1-\mathrm{cm} \times 3-\mathrm{cm}$ slices were obtained from this sample; fiber direction was parallel to the $3 \mathrm{~cm}$ length. Each slice was sheared once in a direction perpendicular to the muscle fibers using an Instron Universal Testing Machine ${ }^{5}$ with a Warner-Bratzler shear attachment. Peak shear values are presented in kilograms as the peak weight required to shear the muscle sample. Calibration of the Instron machine was achieved using a $500-\mathrm{kg}$ load cell with a full scale load of 1 , a preset crosshead speed of $250 \mathrm{~mm} / \mathrm{min}$, and a proportional chart speed ratio of 2:1 (millimeters/minute).

Statistical treatment of data involved an ANOVA using a randomized, complete block design with battery as the block and pen within treatment as the error term (Steel and Torrie, 1980). Treatment means, standard deviations, and analysis of variance were calculated using SAS (1985). Eight single-df contrasts were used to determine treatment differences within

${ }^{5}$ Instron Corp., Canton, MA. age groups. Daily feed consumption data were analyzed for the first $11 \mathrm{~d}$ using single-df contrasts to compare diets on each day.

\section{Results and Discussion}

Initial body weight and final whole body weight were not different at any given feeding treatment $(P>.05$; Table 1$)$. This finding is in agreement with a study by Morgan et al. (1989) that showed that whole body weights of 38- and 56-d-old birds fed CIM were similar to those of control birds. No differences were found in liver weight (Table 1) or liver as a percentage of whole body weight. Cromwell et al. (1988) reported that liver weight was reduced in swine fed CIM and that liver weight was increased after a withdrawal period.

Fat pad weight was not different among treatments (Table 1); however, at $35 \mathrm{~d}$ of age, CIM-fed birds had less fat pad $(P<.01)$ as a percentage of final whole body weight (Table 2). Weights of the BM were not different among feeding treatments $(P>.05)$ regardless of age (Table 2). Leg muscles from 42-d-old CIM-fed birds without withdrawal were heavier than LM from 42-d-old CIM-fed birds with a $7-d$ withdrawal, and $L M$ from 
control birds at $49 \mathrm{~d}$ of age were lighter than LM from CIM-fed birds after 0 or $7 \mathrm{~d}$ of withdrawal. The percentage of whole body weight as LM was elevated by CDM feeding at 35,42 , and $49 \mathrm{~d}$ of age, and BM percentage was greater at $35 \mathrm{~d}$ of age (Table 2).

Birds fed the control diet consumed $71.5 \mathrm{~g}$ of feed the 1 st $d$ of feeding compared with only $59.9 \mathrm{~g}$ for CIM-treated birds, resulting in a $16.3 \%$ decrease in feed intake $(P<.05)$. Feed intake was reduced by $3.7 \%$ after $2 \mathrm{~d}$ of feeding $(P<.05)$ for CIM-fed birds. After this initial decline in feed intake, CIM-fed birds consumed as much feed as control birds through the first $11 \mathrm{~d}$ of the study.

Treatment means and contrasts for proximate composition of the $\mathrm{LM}, \mathrm{BM}$, and whole body are summarized in Tables 3, 4, and 5, respectively. Reduced fat content was found in LM at 35 and $42 \mathrm{~d}$ of age in CM-fed birds compared with control birds $(P<.05)$. Withdrawal from CIM to the control diet for 7 or $14 \mathrm{~d}$ increased $\mathrm{BM}$ fatness above that of birds continuously fed CIM. Whole body fat did not differ $(P>.05)$ at any age (Table 5). Dalrymple et al. (1984) reported that chickens fed $1 \mathrm{ppm}$ clenbuterol had less whole body fat than chickens fed without clenbuterol. Jones et al. (1985) showed that the response to CMM was quickly reversed in swine after a 7-d withdrawal period and that fat deposition increased during the withdrawal time, resulting in swine that were as fat as the controls. Prince et al. (1985) also observed increased fat deposition resulting from CIM withdrawal for $7 \mathrm{~d}$ in swine.

Feeding CIM elevated protein content of the $L M$ at 42 and $49 \mathrm{~d}$ of age, increased protein levels in the BM at 35 and $49 \mathrm{~d}$ of age, and increased protein content of the whole body at $35 \mathrm{~d}$ of age $(P<.05)$ compared with control birds. Withdrawal from CIM to the control diet for 7 or $14 \mathrm{~d}$ removed these differences in protein content for LM $(P>.05)$. Dalrymple et

TABLE 2. THE EFFECTS OF CIMATEROL AND ITS WTTHDRAWAI ON BREAST AND LEG WEIGHTS AND LIVER, FAT PAD, BREAST, AND LEG PERCENTAGE OF FINAL BODY WEIGHT

\begin{tabular}{|c|c|c|c|c|c|c|c|c|c|}
\hline \multirow[b]{4}{*}{ Age and variable } & \multirow{2}{*}{\multicolumn{4}{|c|}{ Treatments $^{a}$}} & \multicolumn{4}{|c|}{ Contrasts } & \multirow[b]{4}{*}{ SEM $^{\mathrm{b}}$} \\
\hline & & & & & \multirow{3}{*}{$\begin{array}{l}\text { CON } \\
\text { vs } \\
\text { owd }\end{array}$} & \multirow{3}{*}{$\begin{array}{l}\text { CON } \\
\text { vs } \\
7 w d\end{array}$} & \multirow{3}{*}{$\begin{array}{l}\text { Owd } \\
\text { vs } \\
7 w d\end{array}$} & \multirow{3}{*}{$\begin{array}{l}\text { Owd } \\
\text { vs } \\
14 w d\end{array}$} & \\
\hline & & & Cimatero & & & & & & \\
\hline & $\mathrm{CON}$ & Owd & $7 w d$ & $14 w d$ & & & & & \\
\hline \multicolumn{10}{|l|}{35 Days } \\
\hline Breast wt, $\mathrm{g}^{\mathrm{c}}$ & 91.66 & 92.70 & - & - & $N S^{d}$ & - & - & - & 2.60 \\
\hline Breast, \% & 7.34 & 7.90 & - & - & $<.05$ & - & - & - & .067 \\
\hline Leg wt, $g^{c}$ & 63.96 & 68.02 & - & - & NS & - & - & - & 1.91 \\
\hline Leg, \% & 5.12 & 5.80 & - & - & $<.05$ & - & - & 一 & .045 \\
\hline Fat pad, \% & 1.94 & 1.45 & - & 一 & $<.05$ & - & - & - & .054 \\
\hline Liver, \% & 2.04 & 1.99 & - & - & NS & - & - & - & .043 \\
\hline \multicolumn{10}{|l|}{42 Days } \\
\hline Breast wt, $\mathbf{g}$ & 128.17 & 130.64 & 120.18 & - & NS & NS & NS & 一 & - \\
\hline Breast, \% & 7.57 & 7.85 & 7.50 & - & NS & NS & NS & 一 & - \\
\hline Leg wt, $g$ & 90.01 & 98.07 & 88.07 & - & NS & NS & $<.05$ & 一 & - \\
\hline Leg, \% & 5.33 & 5.90 & 5.46 & - & $<.05$ & NS & $<05$ & - & - \\
\hline Fat pad, \% & 1.66 & 1.66 & 1.57 & - & NS & NS & NS & - & - \\
\hline Liver, $\%$ & 1.90 & 1.80 & 1.78 & - & NS & NS & NS & 一 & - \\
\hline \multicolumn{10}{|l|}{49 Days } \\
\hline Breast wt, g & 152.57 & 162.45 & 157.54 & 158.11 & NS & NS & NS & NS & - \\
\hline Breast, $\%$ & 7.60 & 7.85 & 7.71 & 7.82 & NS & NS & NS & NS & - \\
\hline Leg wt, g & 108.36 & 123.12 & 117.77 & 114.64 & $<.05$ & $<.05$ & NS & NS & - \\
\hline Leg, $\%$ & 5.43 & 5.95 & 5.74 & 5.67 & $<.05$ & NS & NS & NS & - \\
\hline Fat pad, \% & 2.03 & 2.11 & 1.86 & 2.04 & NS & NS & NS & NS & - \\
\hline Liver, \% & 1.78 & 1.89 & 1.69 & 1.72 & NS & NS & NS & NS & - \\
\hline
\end{tabular}

${ }^{2} \mathrm{CON}=$ chickens fed $0 \mathrm{ppm}$ cimaterol in diet and Cimaterol = chickens fed 1 ppm cimaterol in diet and withdrawn (wd) from cimaterol and fed $0 \mathrm{ppm}$ cimaterol for 0,7 , or $14 \mathrm{~d}$. Number of observations $=12 /$ treatment.

${ }^{\text {b }}$ Standard error of the means represents variables for 35,42 , and $49 \mathrm{~d}$ of age.

'Breast consisted of the Pectoralis major, leg consisted of the combined Gastrocnemius and Peroneous longus.

dNS = nonsignificant differences $(P>.05)$. 
TABLE 3. THE EFFECTS OF CIMATEROL AND ITS WTHDRAWAL ON LEG ${ }^{\mathrm{a}}$ MUSCLE COMPOSITION

\begin{tabular}{|c|c|c|c|c|c|c|c|c|c|}
\hline \multirow[b]{4}{*}{ Age and variable } & \multirow{2}{*}{\multicolumn{4}{|c|}{ Treatments $^{b}$}} & \multicolumn{4}{|c|}{ Contrasts } & \multirow[b]{4}{*}{ SEM $^{C}$} \\
\hline & & & & & \multirow{3}{*}{$\begin{array}{l}\text { CON } \\
\text { vs } \\
\text { Owd } \\
\end{array}$} & \multirow{3}{*}{$\begin{array}{l}\text { CON } \\
\text { vs } \\
7 w d \\
\end{array}$} & \multirow{3}{*}{$\begin{array}{l}\text { Owd } \\
\text { vs } \\
7 w d\end{array}$} & \multirow{3}{*}{$\begin{array}{l}\text { Owd } \\
\text { vs } \\
14 w d\end{array}$} & \\
\hline & & & Cimater & & & & & & \\
\hline & CON & Owd & $7 w d$ & $14 w d$ & & & & & \\
\hline $\begin{array}{l}35 \text { Days } \\
\text { Fat, } \% \\
\text { Protein, } \% \\
\text { Moisture, } \%\end{array}$ & $\begin{array}{r}3.42 \\
19.97 \\
76.44\end{array}$ & $\begin{array}{r}2.66 \\
20.51 \\
76.57\end{array}$ & - & - & $\begin{array}{l}<.05 \\
\mathrm{NS}^{\mathrm{d}} \\
\mathrm{NS}\end{array}$ & - & - & - & $\begin{array}{l}.072 \\
.073 \\
.078\end{array}$ \\
\hline $\begin{array}{l}\text { 42. Days } \\
\text { Fat, \% } \\
\text { Protein, \% } \\
\text { Moisture, \% }\end{array}$ & $\begin{array}{r}3.92 \\
19.89 \\
75.79\end{array}$ & $\begin{array}{r}3.13 \\
20.65 \\
75.99\end{array}$ & $\begin{array}{r}3.56 \\
20.01 \\
76.11\end{array}$ & - & $\begin{array}{l}<.05 \\
<.05 \\
N S\end{array}$ & $\begin{array}{l}\text { NS } \\
\text { NS } \\
\text { NS }\end{array}$ & $\begin{array}{l}\text { NS } \\
\text { NS } \\
\text { NS }\end{array}$ & E & - \\
\hline $\begin{array}{l}49 \text { Days } \\
\text { Fat, \% } \\
\text { Protein, \% } \\
\text { Moisture, \% }\end{array}$ & $\begin{array}{r}3.46 \\
19.98 \\
76.69\end{array}$ & $\begin{array}{r}3.44 \\
20.78 \\
75.76\end{array}$ & $\begin{array}{r}3.66 \\
20.40 \\
76.15\end{array}$ & $\begin{array}{r}3.22 \\
20.49 \\
76.81\end{array}$ & $\begin{array}{l}\text { NS } \\
<.01 \\
<.01\end{array}$ & $\begin{array}{l}\text { NS } \\
\text { NS } \\
<.05\end{array}$ & $\begin{array}{l}\text { NS } \\
\text { NS } \\
\text { NS }\end{array}$ & $\begin{array}{l}\text { NS } \\
\text { NS } \\
<.05\end{array}$ & - \\
\hline
\end{tabular}

${ }^{2} \mathrm{Leg}$ consists of Peroneous longus and Gastrocnemius.

${ }^{\mathrm{b}} \mathrm{CON}=$ chickens fed $0 \mathrm{ppm}$ cimaterol in diet and Cimaterol = chickens fed $1 \mathrm{ppm}$ cimaterol in diet and withdrawn (wd) from cimalerol and fed $0 \mathrm{ppm}$ cimaterol for 0,7 , or $14 \mathrm{~d}$. Number of observations $=12 /$ treatment.

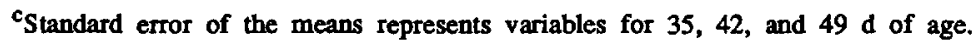

$\mathrm{d}_{\mathrm{NS}}=$ nonsignificant differences $(P>.05)$.

al. (1984) also reported that female chickens fed clenbuterol had higher protein levels than controls.

Moisture content was higher in the LM and BM of control birds at $49 \mathrm{~d}$ of age than in $\mathrm{LM}$ and BM of 49-d-old birds fed CIM and 49-d-old birds fed CIM with $7 \mathrm{~d}$ of withdrawal. Leg muscle of 49-d-old birds fed CIM after $14 \mathrm{~d}$ of withdrawal had more moisture than that of 49-d-old birds continuously fed CIM ( $P$

TABLE 4, THE EFFECTS OF CIMATEROL AND ITS WITHDRAWAL ON BREAST MUSCLE COMPOSITION

\begin{tabular}{|c|c|c|c|c|c|c|c|c|c|}
\hline \multirow[b]{4}{*}{ Age and variable } & \multirow{2}{*}{\multicolumn{4}{|c|}{ Treatments ${ }^{b}$}} & \multicolumn{4}{|c|}{ Contrasts } & \multirow[b]{4}{*}{$\mathrm{SEM}^{\mathrm{c}}$} \\
\hline & & & & & \multirow{3}{*}{$\begin{array}{l}\text { CON } \\
\text { vs } \\
\text { Owd }\end{array}$} & \multirow{3}{*}{$\begin{array}{l}\text { CON } \\
\text { vs } \\
7 w d\end{array}$} & \multirow{3}{*}{$\begin{array}{l}\text { Owd } \\
\text { vs } \\
7 w d\end{array}$} & \multirow{3}{*}{$\begin{array}{l}\text { Owd } \\
\text { vs } \\
14 w d\end{array}$} & \\
\hline & \multirow[b]{2}{*}{ CON } & \multicolumn{3}{|c|}{ Cimaterol } & & & & & \\
\hline & & Owd & $7 w d$ & $14 w d$ & & & & & \\
\hline \multicolumn{10}{|l|}{35 Days } \\
\hline Fat, $\%$ & 1.15 & 1.07 & - & - & $N S^{d}$ & - & - & - & .069 \\
\hline Protein, \% & 23.56 & 24.38 & - & - & $<05$ & - & 一 & - & .081 \\
\hline Moisture, \% & 74.63 & 74.51 & - & - & NS & - & - & 一 & .068 \\
\hline \multicolumn{10}{|l|}{42 Days } \\
\hline Fat, \% & 1.43 & 1.34 & 1.24 & - & NS & NS & NS & - & - \\
\hline Protein, \% & 23.92 & 24.37 & 23.63 & - & NS & NS & NS & - & - \\
\hline Moisture, $\%$ & 74.21 & 74.04 & 74.45 & - & NS & NS & NS & - & - \\
\hline \multicolumn{10}{|l|}{49 Days } \\
\hline Fal, $\%$ & 1.66 & 1.25 & 1.72 & 1.79 & NS & NS & $<.05$ & $<.05$ & - \\
\hline Protein, $\%$ & 24.02 & 24.96 & 23.89 & 24.07 & $<.05$ & NS & $<.01$ & $<.01$ & - \\
\hline Moisture, $\%$ & 74.50 & 73.69 & 73.82 & 74.13 & $<.01$ & $<.05$ & NS & NS & - \\
\hline
\end{tabular}

Breast consists of Pectoralis major.

${ }^{b} \mathrm{CON}=$ chickens fed 0 cimaterol in diet and Cimaterol = chickens fed 1 ppm cimaterol in diet and withdrawn (wd) from cimaterol and fed $0 \mathrm{ppm}$ cimaterol for 0,7 , or $14 \mathrm{~d}$. Number of observations $=12 /$ treatment.

'Standard error of the means represents variables for 35,42 , and $49 \mathrm{~d}$ of age.

dNS = nonsignificant differences $(P>.05)$. 
TABLE 5. THE EFFECTS OF CIMATEROL AND ITS WTTHDRAWAL ON WHOLE BODY COMPOSITION ${ }^{a}$

\begin{tabular}{|c|c|c|c|c|c|c|c|c|c|}
\hline \multirow[b]{4}{*}{ Age and variable } & \multirow{2}{*}{\multicolumn{4}{|c|}{ Treatments $^{b}$}} & \multicolumn{4}{|c|}{ Contrasts } & \multirow[b]{4}{*}{$\mathbf{S E M}^{\mathrm{C}}$} \\
\hline & & & & & \multirow{3}{*}{$\begin{array}{l}\text { CON } \\
\text { vs } \\
\text { Owd }\end{array}$} & \multirow{3}{*}{$\begin{array}{l}\text { CON } \\
\text { vs } \\
7 \text { wd }\end{array}$} & \multirow{3}{*}{$\begin{array}{l}\text { Owd } \\
\text { vs } \\
7 \text { wd }\end{array}$} & \multirow{3}{*}{$\begin{array}{l}\text { Owd } \\
\text { vs } \\
14 \text { wd }\end{array}$} & \\
\hline & & & Cimate & & & & & & \\
\hline & CON & Owd & $7 w d$ & $14 w d$ & & & & & \\
\hline $\begin{array}{l}35 \text { Days } \\
\text { Fat, \% } \\
\text { Protein, \% } \\
\text { Moisture, \% }\end{array}$ & $\begin{array}{l}14.14 \\
17.48 \\
65.78\end{array}$ & $\begin{array}{l}13.79 \\
18.54 \\
65.16\end{array}$ & $\overline{-}$ & - & $\begin{array}{l}\mathrm{NS}^{\mathrm{d}} \\
<.05 \\
\mathrm{NS}\end{array}$ & Z & $\bar{z}$ & E & $\begin{array}{l}.003 \\
.001 \\
.003\end{array}$ \\
\hline $\begin{array}{l}42 \text { Days } \\
\text { Fat, } \% \\
\text { Protein, \% } \\
\text { Moisture, \% }\end{array}$ & $\begin{array}{l}15.06 \\
18.49 \\
63.49\end{array}$ & $\begin{array}{l}13.48 \\
19.41 \\
64.43\end{array}$ & $\begin{array}{l}14.33 \\
18.58 \\
64.42\end{array}$ & E & $\begin{array}{l}\text { NS } \\
\text { NS } \\
\text { NS }\end{array}$ & $\begin{array}{l}\text { NS } \\
\text { NS } \\
\text { NS }\end{array}$ & $\begin{array}{l}\text { NS } \\
\text { NS } \\
\text { NS }\end{array}$ & E & E \\
\hline $\begin{array}{l}49 \text { Days } \\
\text { Fat, \% } \\
\text { Protein, \% } \\
\text { Moisture, \% }\end{array}$ & $\begin{array}{l}15.75 \\
18.52 \\
63.18 \\
\end{array}$ & $\begin{array}{l}15.18 \\
19.12 \\
63.39 \\
\end{array}$ & $\begin{array}{l}16.80 \\
19.29 \\
61.30 \\
\end{array}$ & $\begin{array}{l}15.66 \\
18.90 \\
63.02 \\
\end{array}$ & $\begin{array}{l}\text { NS } \\
\text { NS } \\
\text { NS } \\
\end{array}$ & $\begin{array}{l}\text { NS } \\
\text { NS } \\
\text { NS }\end{array}$ & $\begin{array}{l}\text { NS } \\
\text { NS } \\
<.05\end{array}$ & $\begin{array}{l}\text { NS } \\
\text { NS } \\
\text { NS } \\
\end{array}$ & $\overline{-}$ \\
\hline
\end{tabular}

ahole body contained internal organs that were stripped of fecal material and feed before composition was determined.

${ }^{b} \mathrm{CON}=$ chickens fed $0 \mathrm{ppm}$ cimaterol in diet and Cimaterol = chickens fed $1 \mathrm{ppm}$ cimaterol in diet and withdraw (wd) from cimaterol and fed $0 \mathrm{ppm}$ cimaterol for 0,7 , or $14 \mathrm{~d}$. Number of observations $=12 /$ treatment.

${ }^{c_{S t a n d a r d}}$ error of the means represents variables for 35,42 , and $49 \mathrm{~d}$ of age.

dNS = nonsignificant differences $(P>.05)$.

$<.05)$. Whole body moisture was not different $(P>.05$ ) except at $49 \mathrm{~d}$, when CIM-fed birds had more moisture than 49-d-old birds fed CIM followed by a 7-d withdrawal period.
Breast muscle shear values were increased in $42-$ and $49-\mathrm{d}$-old birds fed CIM by 48 and 40\% (Table 6), respectively $(P<.05)$. Shear values of BM from birds withdrawn from CIM

TABLE 6. THE EFFECTS OF CIMATEROL AND ITS WITHDRAWAL ON CATHEPSIN B AND I ACTIVITY OF BREAST AND LEG MUSCLE AND SHEAR VALUES (SV) OF BREAST MUSCLE:

\begin{tabular}{|c|c|c|c|c|c|c|c|c|c|}
\hline \multirow[b]{4}{*}{ Age and variable } & \multirow{2}{*}{\multicolumn{4}{|c|}{ Treatments $^{2}$}} & \multicolumn{4}{|c|}{ Contrasts } & \multirow[b]{4}{*}{$\operatorname{SEM}^{\mathrm{b}}$} \\
\hline & & & & & \multirow{3}{*}{$\begin{array}{l}\text { CON } \\
\text { vs } \\
\text { Owd }\end{array}$} & \multirow{3}{*}{$\begin{array}{l}\text { CON } \\
\text { vs } \\
7 \text { wd }\end{array}$} & \multirow{3}{*}{$\begin{array}{l}\text { Owd } \\
\text { vs } \\
7 \text { wd }\end{array}$} & \multirow{3}{*}{$\begin{array}{l}\text { Owd } \\
\text { vs } \\
14 w d\end{array}$} & \\
\hline & \multirow[b]{2}{*}{ CON } & \multicolumn{3}{|c|}{ Cimaterol } & & & & & \\
\hline & & Owd & $7 w d$ & $14 w d$ & & & & & \\
\hline \multirow{4}{*}{$\begin{array}{l}35 \text { Days } \\
\text { Breast }^{c} \text { SV } \\
\text { Cathepsin B and L, Breast } \\
\text { Cathepsin B and L, Legc }\end{array}$} & & & & & & & & & \\
\hline & 1.98 & 2.40 & - & - & $\mathbf{N S}^{\mathrm{d}}$ & - & - & - & .121 \\
\hline & $5.68^{\mathrm{e}}$ & 4.77 & 一 & 一 & NS & - & 一 & 一 & .139 \\
\hline & 0.97 & 1.02 & 一 & - & NS & - & - & - & .068 \\
\hline \multicolumn{10}{|l|}{42 Days } \\
\hline Breast SV & 2.30 & 3.50 & 2.43 & - & $<.05$ & NS & NS & - & - \\
\hline Cathepsin B and L, Breast & 3.44 & 3.40 & 2.97 & - & NS & NS & NS & - & - \\
\hline Cathepsin B and L, Leg & 1.70 & 2.07 & 2.00 & 一 & NS & NS & NS & - & - \\
\hline \multicolumn{10}{|l|}{49 Days } \\
\hline Breast SV and L, Leg & 2.68 & 3.74 & 2.46 & 2.98 & $<.05$ & NS & $<.01$ & NS & - \\
\hline Cathepsin B and L, Breast & 3.56 & 4.19 & 3.66 & 3.24 & NS & NS & NS & NS & - \\
\hline Cathepsin B and L, Leg & 1.25 & 1.74 & 1.25 & 1.40 & NS & NS & NS & NS & - \\
\hline
\end{tabular}

${ }^{a} \mathrm{CON}=$ chickens fed $0 \mathrm{ppm}$ cimaterol in diet and Cimaterol = chickens fed $1 \mathrm{ppm}$ cimaterol in diet and withdrawn (wd) from cimaterol and fed $0 \mathrm{ppm}$ cimaterol for 0,7 , or $14 \mathrm{~d}$. Number of observations $=12 /$ treatment.

${ }^{b}$ Standard error of the means represents variables for 35,42 , and $49 \mathrm{~d}$ of age.

'Breast consisted of the Pectoralis major, Leg consisted of the Peroneous longus and Gastrocnemius.

NS $=$ nonsignificant differences $(P<.05)$.

'Total activity, nanoMolar/milligram of protein/minute. 
for $7 \mathrm{~d}$ at 35 or $42 \mathrm{~d}$ of age and given the control diet were similar to shear values of $\mathbf{B M}$ from birds fed the control diet throughout the study $(P>.05)$. Morgan et al. (1989) showed that chickens fed cimaterol at $1 \mathrm{ppm}$ had higher shear values and were tougher than controls at 38 and $56 \mathrm{~d}$ of age. Schiavetta et al. (1988) reported that shear values of loin steaks from cattle fed the beta-agonist clenbuterol were greater than those of controls, but this increase in shear value was minimized after a 90-d withdrawal period.

Calkins et al. (1987) have suggested that there is a relationship between enzyme activities (namely cathepsin B) and meat tenderness. Kretchmar et al. (1990) reported a decrease in cathepsin B activity in lambs fed the beta-agonist L-644,969. Forsberg et al. (1987) also showed a decrease (45\%) in cathepsin B activity in lambs fed cimaterol. Total cathepsin $B$ and $L$ activities of BM and LM were not different $(P>.05)$ among treatments, regardless of age. At $35 \mathrm{~d}$ of age, BM of control birds had a higher total activity of cathepsin B and $L$ (not significant) than BM of CIM-fed birds at $35 \mathrm{~d}$ of age (Table 6). However, this was not consistent at 42 and 49 d of age. This result is inconsistent with the findings of Morgan et al. (1989), who found shear value to be negatively correlated to cathepsin enzyme activity in broiler chickens fed 1 ppm CIM. Higher cathepsin B and L activities were associated with BM, which is predominantly made up of white muscle fibers.

Recently, procedures have been published that provide a technique to remove at least some of the cystatin inhibitors from a catheptic enzyme preparation before assay for activity (Koohmaraie and Kretchmar, 1990). Such a technique may provide greater insight into the mechanisms of control over enzyme activity. One would expect that whatever enzyme activity exists in vivo would have to function beyond the level of any endogenous inhibition, as was measured in this study.

The results of this study suggest that a diet containing $1 \mathrm{ppm}$ CIM increases chicken muscle protein and decreases fatness. Also, CIM-treated chickens that were not withdrawn from the treatment had increased shear values (lower meat tenderness). Withdrawal of CIM from the diet helped to alleviate the reduction in tenderness due to CIM, however, withdrawal from CIM for 7 or $14 \mathrm{~d}$ also removed advantages in composition.

\section{Implications}

If cimaterol is approved for use in poultry diets, a withdrawal period before slaughter may become necessary. In this study, a withdrawal period from cimaterol resulted in no advantage in carcass composition of broiler chickens. Tenderness of the breast muscle was reduced by feeding cimaterol; however, the shear values obtained from birds fed cimaterol were still acceptable in terms of tenderness.

\section{Literature Clted}

AOAC. 1985. Official Methods of Analysis (14th Ed.). Association of Official Analytical Chemists, Washington, DC.

Barrett, A. J. 1980. Fluorimetric assays for cathepsin B and cathepsin $\mathrm{H}$ with methylcoumarylamide substrates. Biochem. J. 187:909.

Barrett, A. J. and H. Kirschke. 1981. Cathepsin B, Cathepsin H, and Cathepsin L. Methods Enzymol. 80:535.

Beermann, D. H., D. E. Hogue, V. K. Fishell, R. H. Dalrymple and C. A. Ricks. 1986. Effects of cimaterol and fishmeal on performance, carcass characteristics and skeletal muscle growth in lambs. J. Anim. Sci. 62: 370.

Calkins, C. R., S. C. Seideman and J. D. Crouse. 1987. Relationships between rate of growth, catheptic enzymes and meat palatability in young bulls. J. Anim. Sci. 64:1448.

Cromwell, G. L., J. D. Kemp, T. S. Stahly and R. H. Dalrymple. 1988. Effects of dietary level and withdrawal time on the efficacy of cimaterol as a growth repartitioning agent in finishing swine. J. Anim. Sci. 66:2193.

Dalrymple, R. H., P. K. Baker, P. E. Gingher, D. L. Ingle, J. M. Pensack and C. A. Ricks. 1984. A repartitioning agent to improve performance and carcass composition of broilers. Poult. Sci. 63:2376.

Forsberg, N. E., A. R. Nassar, R. H. Dalrymple and C. A. Ricks. 1987. Cimaterol reduces cathepsin $B$ activity in sheep skeletal muscle. Fed. Proc. 46:1176 (Abstr. \# 5009).

Gornall, A. G., C. J. Bordawill and M. M. David. 1949. Determination of serum proteins by means of the biuret reaction. J. Biol. Chem. 177:751.

Jones, R. W., R. A. Easter, F. K. McKeith, R. H. Dalrymple, H. M. Maddock and P. J. Bechtel. 1985. Effect of the $\beta$ adrenergic agonist cimaterol (CL263,780) on the growth and carcass characteristics of finishing swine. J. Anim. Sci. 61:905.

Koohmaraie, M. and D. H. Kretchmar. 1990. Comparisons of four methods of quantification of lysosomal cysteine proteinase activities. J. Anim. Sci. 68:2362.

Kretchmar, D. H., M. R. Hathaway, R. J. Epley and W. R. Dayton. 1990. Alterations in postmortem degradation of myofibrillar proteins in muscle of lambs fed a $\beta$ adrenergic agonist. J. Anim. Sci. 68:1760.

Moeller, P. W., P. A. Fields, T. R. Dutson, W. A. Landmann and Z. L. Carpenter. 1976. Effect of high temperature conditioning on subcellular distribution and levels of lysosomal enzymes. J. Food Sci. 41:216.

Morgan, J. B., S. J. Jones and C. R. Calkins. 1989. Muscle 
protein turnover and tenderness in broiler chickens fed cimaterol. J. Anim. Sci. 67:2646.

Prince, T. J., R. H. Dalrymple and D. N. Marple. 1985. Effects of feeding cimaterol (CL 263,780) on performance and carcass characteristics of finishing pigs. $J$. Anim. Sci. 61(Suppl. 1):301 (Abstr.).

SAS. 1985. SAS User's Guide: Statistics. SAS Inst., Inc., Cary, NC.
Schiavetta, A. M., M. F. Miller, D. K. Lunt and S. B. Smith. 1988. Changes in adipose tissue cellularity, lipogenic rates and carcass characteristics in steers fed clenbuterol for 50 days and after 90 days withdrawal. J. Anim. Sci. 66(Suppl. 1):251 (Abstr.).

Steel, R.G.D. and J. H. Torrie. 1980. Principles and Procedures of Statistics: A Biometrical Approach (2nd Ed.). McGraw-Hill Book Co., New York. 